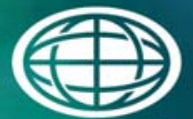

Savannah River

National Laboratory "m

OPERATED BY SAVANNAH RIVER NUCLEAR SOLUTIONS

\title{
High-Temperature Oxidation of Stainless Steel for Fuel Cladding Removal
}

\section{T. C. Shehee \\ R. A. Pierce}

September 2014

SRNL-STI-2014-00432, Revision 0 


\section{DISCLAIMER}

This work was prepared under an agreement with and funded by the U.S. Government. Neither the U.S. Government or its employees, nor any of its contractors, subcontractors or their employees, makes any express or implied:

1. warranty or assumes any legal liability for the accuracy, completeness, or for the use or results of such use of any information, product, or process disclosed; or

2. representation that such use or results of such use would not infringe privately owned rights; or

3. endorsement or recommendation of any specifically identified commercial product, process, or service.

Any views and opinions of authors expressed in this work do not necessarily state or reflect those of the United States Government, or its contractors, or subcontractors.

\section{Printed in the United States of America \\ Prepared for U.S. Department of Energy}


Keywords: decladding, stainless steel, induction heating

Retention: Permanent

\section{High-Temperature Oxidation of Stainless Steel for Fuel Cladding Removal}

T. C. Shehee

R. A. Pierce

September 2014

Prepared for the U.S. Department of Energy under contract number DE-AC09-08SR22470. 


\section{REVIEWS AND APPROVALS}

\section{AUTHORS:}

T. C. Shehee, Separation \& Actinide Science

Date

R. A. Pierce, Separation \& Actinide Science

Date

TECHNICAL REVIEW:

M. C. Thompson, Separation \& Actinide Science

Date

APPROVAL:

T. B. Brown, Manager

Date

Separation \& Actinide Science

S. L. Marra, Manager

Date

Environmental \& Chemical Process Technology Research Programs 
SRNL-STI-2014-00432

Revision 0

\section{EXECUTIVE SUMMARY}

The Savannah River National Laboratory (SRNL) has been asked to explore alternate methods for decladding spent nuclear fuel. Of particular interest is the processing of stainless steel and zirconium clad fuels. However, the processing of clad fuel is bound by significant constraints associated with handling spent nuclear fuel in remote-handled environments. Several methods have been proposed for processing spent fuel using aggressive chemical, thermal, or mechanical methods. The most-common method used by industry is mechanical chop-leach or laser chop-leach where the fuel is cut into nominal one-inch segments and then the uranium in the fuel tubes is leached out of the segmented tubes using nitric acid. It is the assessment of Savannah River Site (SRS) subject matter experts that versions of chop-leach are prohibitively expensive for application at SRS.

The literature suggests another approach that would meet many of the characteristics of an ideal process. Fuel rods were perforated at a spacing of about one inch. After the perforations were complete, the fuel tubes were heated in air. As a result of heating in air, the fuel meat in the fuel tubes reacted with air, expanded, ruptured the stainless steel cladding at the perforations, and exposed the fuel meat for dissolution. However, that approach would require a method for perforating each individual fuel rod.

If the cladding could be weakened by an alternative method, perhaps the fuel rods would rupture and expose the fuel meat. One possible approach is high-temperature oxidation with air or steam. Under such conditions, the oxidized stainless steel may be brittle and friable enough to rupture when the fuel meat inside of the cladding expands. The results of these scoping studies indicate that it may be possible to breach stainless steel clad fuels and access the fuel meat in a similar manner.

Testing with 304L stainless steel coupons and tubes in a muffle furnace at temperatures near the melting point of 304L has shown that 304L tubing oxidizes readily to a brittle material. When 304L tubing is passed through an induction field to produce similar temperatures in the tube, the damage to the tube occurs faster and is more extensive than observed when heating the materials in a muffle furnace.

Experiments using tubes packed with $\mathrm{Fe}, \mathrm{V}$, and Ta metal powders showed that if the material inside the tube expands while the tube is made brittle through oxidation, cracking and perforation of the tube will occur along the length of the tube. The extent of damage was dependent upon metal powder used for testing. It is not known if any of the packing materials tested accurately represent the effect of $\mathrm{UO}_{2}$ inside stainless steel tubes expanding as it is oxidized. The next stage of testing should consider the oxidation of an unirradiated fuel rod in an induction field. 


\section{TABLE OF CONTENTS}

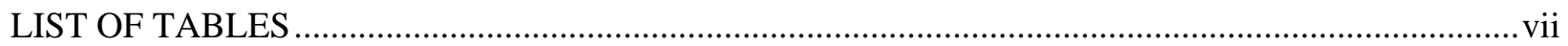

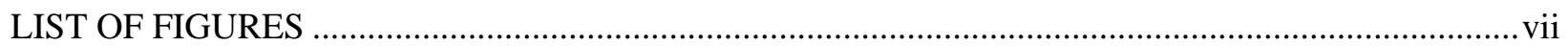

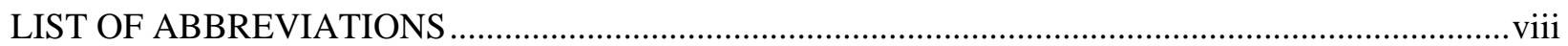

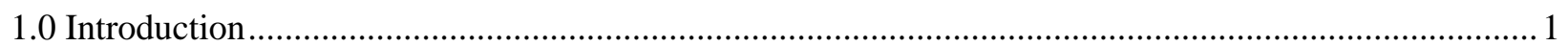

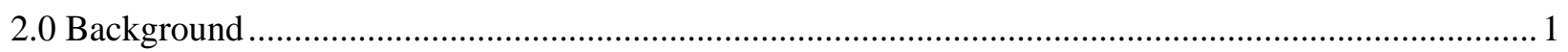

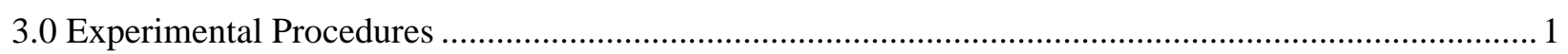

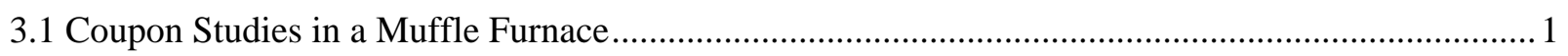

3.2 Studies with Tubes in an Induction Field ................................................................................. 3

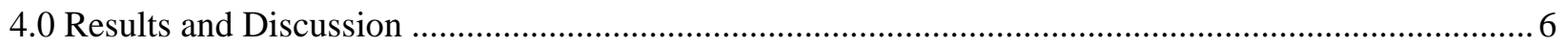

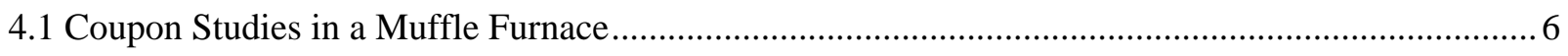

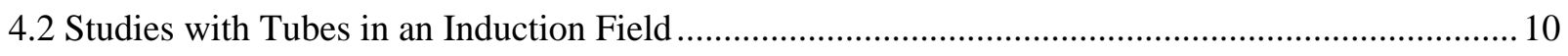

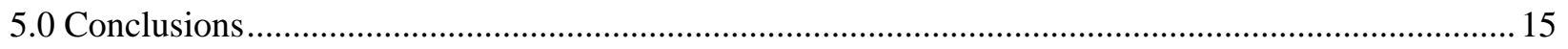

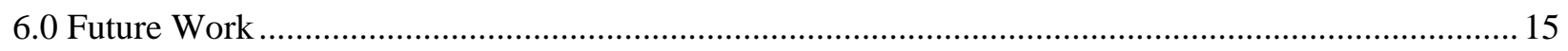

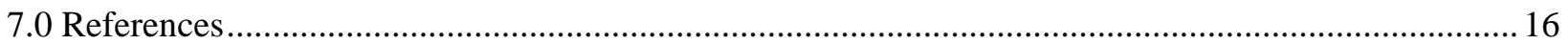




\section{LIST OF TABLES}

Table 3-1. Samples and Test Conditions for Oxidation of 304L Coupons and Tube Segments..................2

Table 3-2. Conditions for Oxidation of Packed Tube Segments in a Muffle Furnace................................ 3

Table 3-3. Amperage-Temperature Data for Open and Closed Tubes ..................................................... 5

Table 3-4. Conditions for Oxidation of Tube Segments in an Induction Field......................................... 6

Table 4-1. Oxidation of 304L Stainless Steel Coupons and Tube Segments........................................... 7

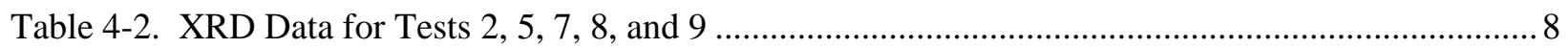

Table 4-3. Observations for Oxidation of Tube Segments in an Induction Field ................................... 10

\section{LIST OF FIGURES}

Figure 3-1. Equipment for Oxidation of Samples in an Induction Field................................................ 4

Figure 3-2. Amperage-Temperature Profiles for Open and Closed Tubes ….......................................... 5

Figure 4-1. Comparison of Initial and Final Samples for Test 2 (left) and Test 9 (right)......................... 7

Figure 4-2. Comparison of Initial and Final Samples for Test 2 (left) and Test 9 (right)......................... 7

Figure 4-3. Fractured Samples for Test 6 (top) and Test 7 (bottom) ….................................................. 8

Figure 4-4. Tube Packed with Iron after Oxidation in Muffle Furnace at $1375{ }^{\circ} \mathrm{C}$.................................. 9

Figure 4-5. Tube Packed with Vanadium after Oxidation in Muffle Furnace at $1375{ }^{\circ} \mathrm{C}$......................... 9

Figure 4-6. Tube Packed with Tantalum after Oxidation in Muffle Furnace at $1375^{\circ} \mathrm{C}$........................ 10

Figure 4-7. Tubes Packed with Iron after Oxidation in an Induction Field ........................................... 11

Figure 4-8. Comparison of Tubes B and D after Oxidation in an Induction Field .................................. 12

Figure 4-9. Tubes Packed with Tantalum after Oxidation in an Induction Field.................................... 13

Figure 4-10. Empty Alloy 625 Tubes after Oxidation in an Induction Field......................................... 14

Figure 4-11. Empty Alloy 625 Tube after Oxidation in an Induction Field - Before Probing (top) and

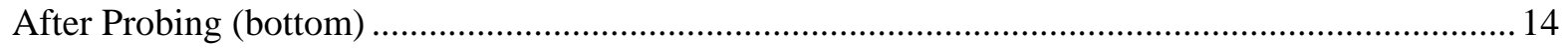




\section{LIST OF ABBREVIATIONS}

psi pounds per square inch

SRNL Savannah River National Laboratory

SRS Savannah River Site

XRD X-ray Diffraction 


\subsection{Introduction}

The Savannah River National Laboratory (SRNL) has been asked to explore alternate methods for decladding spent nuclear fuel. Of particular interest is the processing of stainless steel and zirconium clad fuels. However, the processing of clad fuel is bound by significant constraints associated with handling spent nuclear fuel in remote-handled environments. The ideal process for the Savannah River Site (SRS) would have the following characteristics.

1) Compatible with SRS Canyon operations

2) Simple process equipment concepts

3) Limited equipment and fuel handling

4) Suitable for various fuel bundle designs

5) Does not require fuel bundle disassembly

6) Little or no impact to the liquid waste system

7) Based on known technical concepts

8) Relatively benign process conditions

\subsection{Background}

Several methods have been proposed for processing spent fuel using aggressive chemical, thermal, or mechanical methods. ${ }^{[1]}$ The most-common method used by industry is mechanical chop-leach ${ }^{[2]}$ or laser chop-leach $^{[3]}$ where the fuel is cut into nominal one-inch segments and then the uranium in the fuel tubes is leached out of the segmented tubes using nitric acid. It is the assessment of SRS subject matter experts that versions of chop-leach are prohibitively expensive for application at SRS. ${ }^{[4]}$

Chemical decladding approaches have involved the use of either sulfuric acid or hydrochloric. In the large quantities required, both acids are incompatible with SRS waste streams. ${ }^{[5][6]}$ Zirconium-clad fuels have been processed using solutions with high fluoride concentrations. ${ }^{[7]}$ Reactive gases at elevated temperatures, such as $\mathrm{HF}$ or $\mathrm{SF}_{6}$, have also been proposed but both would pose large off gas and waste handling issues.

The literature suggests another approach that would meet many of the characteristics of an ideal process. $^{[8]}$ In the 1960s, fuel rods were perforated at a spacing of about one inch. After the perforations were complete, the fuel tubes were heated in air. As a result of heating in air, the $\mathrm{UO}_{2}$ in the fuel tubes reacted with air, expanded $\sim 30 \%$ (theoretical), ruptured the stainless steel cladding at the perforations, and exposed the fuel meat for dissolution. While attractive, if it is necessary to process the fuel without disassembling the fuel bundles, the perforation step cannot occur.

If the cladding could be weakened by an alternative method, perhaps the fuel rods would rupture and expose the fuel meat. One possible approach is high-temperature oxidation with air or steam. ${ }^{[9][10][11]}$ Several studies associated with fuel failure during accident scenarios show that stainless steel can be effectively oxidized in steam at $1200-1375{ }^{\circ} \mathrm{C}$ and in air at $1360-1385{ }^{\circ} \mathrm{C}$. Under such conditions, the oxidized stainless steel may be brittle and friable enough to rupture when the $\mathrm{UO}_{2}$ inside the cladding expands upon conversion to $\mathrm{U}_{3} \mathrm{O}_{8}$.

\subsection{Experimental Procedures}

\subsection{Coupon Studies in a Muffle Furnace}

The first stage of studies was completed using 304L stainless steel coupons and tubing segments heated in a muffle furnace. Seven experiments were completed with rectangular coupons and two with tubing 
segments. In each case, the initial mass and thickness of the samples were recorded; the mass of an alumina $\left(\mathrm{Al}_{2} \mathrm{O}_{3}\right)$ crucible was also recorded. The sample was then placed into an alumina crucible and introduced to the furnace. The furnace and sample were heated to a pre-determined temperature for a specified amount of time. At the completion of the heating cycle, the sample was cooled to room temperature, weighed, visual observations were conducted, and some samples were analyzed using X-ray Diffraction (XRD). A list of samples and test conditions is provided in Table 3-1.

Table 3-1. Samples and Test Conditions for Oxidation of 304L Coupons and Tube Segments

\begin{tabular}{|c|c|c|c|c|c|c|}
\hline Test & Sample Type & $\begin{array}{c}\text { Initial } \\
\text { Mass (g) }\end{array}$ & $\begin{array}{c}\text { Thickness } \\
(\mathbf{m m})\end{array}$ & $\begin{array}{c}\text { Furnace } \\
\text { Temp }\left({ }^{\circ} \mathbf{C}\right)\end{array}$ & $\begin{array}{c}\text { Time at } \\
\text { Temp (min) }\end{array}$ & XRD? \\
\hline 1 & Coupon & 4.7402 & 1.16 & 1350 & 15 & No \\
\hline 2 & Coupon & 4.5274 & 1.16 & 1350 & 30 & Yes \\
\hline 3 & Coupon & 4.5499 & 1.16 & 1350 & 60 & No \\
\hline 4 & Coupon & 4.5448 & 1.16 & 1375 & 15 & No \\
\hline 5 & Coupon & 4.6852 & 1.16 & 1375 & 30 & Yes \\
\hline 6 & Coupon & 4.4813 & 1.16 & 1375 & 60 & No \\
\hline 7 & Coupon & 4.5475 & 1.16 & 1400 & 15 & Yes \\
\hline 8 & Tube Segment & 9.0595 & 0.91 & 1375 & 60 & Yes \\
\hline 9 & Tube Segment & 8.8677 & 0.91 & 1385 & 60 & Yes \\
\hline
\end{tabular}

Subsequently, stainless steel tube segments were packed with fines of iron (Fe) metal, tantalum (Ta) metal, and vanadium (V) metal to identify a metal that would produce expansion due to air oxidation. The Fe powder was 99\% (metals basis), -20 mesh from Alfa Aesar. The V powder was 99.5\% (metals basis), 325 mesh from Alfa Aesar. The Ta powder was 99.98\% (metals basis), 100 mesh from Alfa Aesar. The tube segments were 304L stainless steel measuring $10.5 \mathrm{~mm}$ outside diameter, $1.02 \mathrm{~mm}$ wall thickness, and 68-77 $\mathrm{mm}$ long.

The tubes were packed using a hydraulic press and a pellet die that made use of a bottom section from a commercially available pellet die, a 4" body machined from stainless steel, and a packing rod made from a cut off drill bit. The die set was fabricated by the SRNL Machine Shop. The base and body of the die were assembled by placing the body on top of the base. The inside of the die body and the outside of the tube were coated with a 5\% steric acid / alcohol solution. The steric acid acts as a high pressure lubricant to minimize galling between the sample tube and the die body. The sample tube was inserted into the die body and filled to $\sim 1 \mathrm{~cm}$ from the top of the tube. The packing rod was inserted into the die body and the entire assembly was placed on a bench top hydraulic press. The packing rod OD was slightly smaller than the ID of the tube. Once placed in the press, pressure was increased slowly with several releases of the pressure to ensure the packing rod was lined up correctly with the body to minimize galling. Tubes were pressed to a maximum pressure of $4000-8000$ pounds per square inch (psi). On completion of the packing, the tube was pressed out of the die body

Test conditions for the packed tubes are listed in Table 3-2. For the Fe metal powder, the tube was pressed to $4000 \mathrm{psi}$. The powder depth in the tube was $\sim 40 \mathrm{~mm}$. The Fe-packed tube was heated to $1375{ }^{\circ} \mathrm{C}$ in air in the muffle furnace for one hour, inspected, two additional hours, inspected, and a final two hours (total of five hours at temperature). For the $\mathrm{V}$ metal powder, the tube was pressed to 7000 psi. The powder depth in the tube was $30.3 \mathrm{~mm}$. For the Ta metal powder, the tube was pressed to $8000 \mathrm{psi}$ with a final powder depth of $11.5 \mathrm{~mm}$. The V-packed and Ta-packed tubes were heated to $1375{ }^{\circ} \mathrm{C}$ in air for one hour, cooled, and inspected. 
Table 3-2. Conditions for Oxidation of Packed Tube Segments in a Muffle Furnace

\begin{tabular}{|c|c|c|c|c|c||}
\hline Test & Packing & $\begin{array}{c}\text { Packing } \\
\text { Pressure (psi) }\end{array}$ & $\begin{array}{c}\text { Packing } \\
\text { Depth (mm) }\end{array}$ & $\begin{array}{c}\text { Furnace Temp } \\
\left({ }^{\circ} \mathbf{C}\right)\end{array}$ & $\begin{array}{c}\text { Time at } \\
\text { Temp (min) }\end{array}$ \\
\hline 10 & Fe metal & 4000 & $\sim 40$ & 1375 & 300 \\
\hline 11 & V metal & 7000 & 30.3 & 1375 & 60 \\
\hline 12 & Ta metal & 8000 & 11.5 & 1375 & 60 \\
\hline
\end{tabular}

\subsection{Studies with Tubes in an Induction Field}

A series of studies was conducted with 304L stainless steel tubing (12.6-12.7 mm outside diameter, 0.86$0.90 \mathrm{~mm}$ wall thickness, $72-75 \mathrm{~mm}$ long). Test variables included temperature, time at temperature, packed versus unpacked tubes, packing material, and presence or absence of steam. A picture of the equipment for oxidation of tube segments is shown in Figure 3-1. The induction field is generated with an Ameritherm HotShot 3.5 induction heater - the unit is capable of $3.5 \mathrm{~kW}$. The coil inside diameter is $32 \mathrm{~mm}$ and the coil height is $17 \mathrm{~mm}$. The induction heater was cooled with a Neslab Thermoflex 900 recirculating chiller set at $25^{\circ} \mathrm{C}$.

Tests were performed with both empty and packed 304L tubes and empty Alloy 625 tubes. The 304L tubes were packed with powders of Fe metal and Ta metal. The Fe powder was 99\% (metals basis), -20 mesh, from Alfa Aesar. The Ta powder was 99.9\% (metals basis), -22 mesh, from Alfa Aesar. The tubes were packed in the manner described in Section 3.1. The tubes were oxidized while passing the packed tube through the induction field.

The first tests were completed with stationary samples of empty 304L tubes. The 304L tube sample was loaded into the sample holder and held in place with two set screws. The sample holder was secured in the sample advance mechanism with two other set screws. The sample is positioned with sample centered in the opening of the induction coil and the bottom of the sample $\sim 0.5 \mathrm{~cm}$ below the bottom of the induction coil. The induction coil was then turned on at a specified amperage for a specific amount of time. At the conclusion of the test, the power was turned off and the sample cooled to ambient temperature for visual inspection.

During this stage of testing, the temperature at the center of the coil as a function of amperage was measured. This was necessary because testing with packed tubes made it impossible to have a thermocouple in the center of the field during testing. The amperage-temperature profile was measured for both an open tube and a tube with a sealed end on the side in the induction field; both tubes were empty. Temperature with the closed tube was measured using a Type $\mathrm{K}$ thermocouple attached to an Omega HH22 thermocouple reader. The temperature for the open tube was measured using a Type S thermocouple attached to a millivolt (Fluke Model 177) reader. The millivolt readings were converted to temperature using standard tables. ${ }^{[12]}$ These data are listed in Table 3-3 and plotted in Figure 3-2. These data were used as a guide for selection of test settings. For the selected amperage range used during testing, there was little difference in the temperature of the open and closed tubes (based on extrapolation of the closed-tube data). 


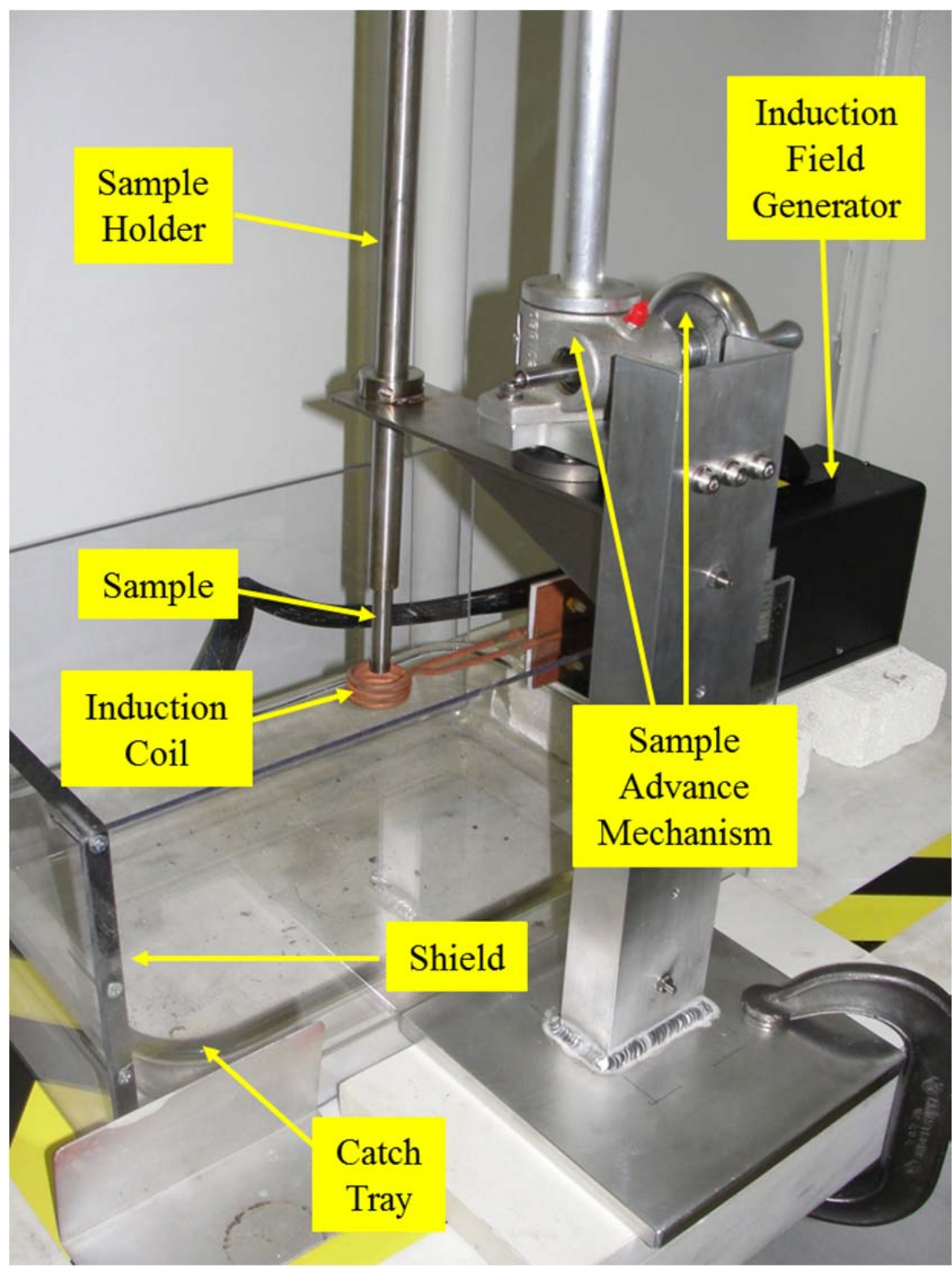

Figure 3-1. Equipment for Oxidation of Samples in an Induction Field 
Table 3-3. Amperage-Temperature Data for Open and Closed Tubes

\begin{tabular}{|c|c|c|c|c|}
\hline $\begin{array}{c}\text { Closed Tube } \\
\text { Power (amps) }\end{array}$ & $\begin{array}{c}\text { Closed Tube } \\
\text { Temp }\left({ }^{\circ} \mathbf{C}\right)\end{array}$ & $\begin{array}{c}\text { Open Tube } \\
\text { Power (amps) }\end{array}$ & $\begin{array}{c}\text { Open Tube } \\
\text { Reading (mV) }\end{array}$ & $\begin{array}{c}\text { Open Tube } \\
\text { Temp }\left({ }^{\circ} \mathbf{C}\right)\end{array}$ \\
\hline 0 & 23 & 0 & 0 & 23 \\
\hline 49.4 & 320 & 49.4 & -1.4 & 193 \\
\hline 75.2 & 545 & 75.2 & -3.4 & 398 \\
\hline 101.0 & 730 & 101 & -5.1 & 557 \\
\hline 124.7 & 868 & 124.7 & -6.6 & 688 \\
\hline 150.5 & 1000 & 150.5 & -8.3 & 828 \\
\hline 174.1 & 1080 & 174.1 & -9.8 & 945 \\
\hline 199.9 & 1176 & 199.9 & -11.4 & 1067 \\
\hline 219.3 & 1238 & 219.3 & -12.5 & 1147 \\
\hline 225.7 & 1260 & 225.7 & -12.8 & 1169 \\
\hline
\end{tabular}

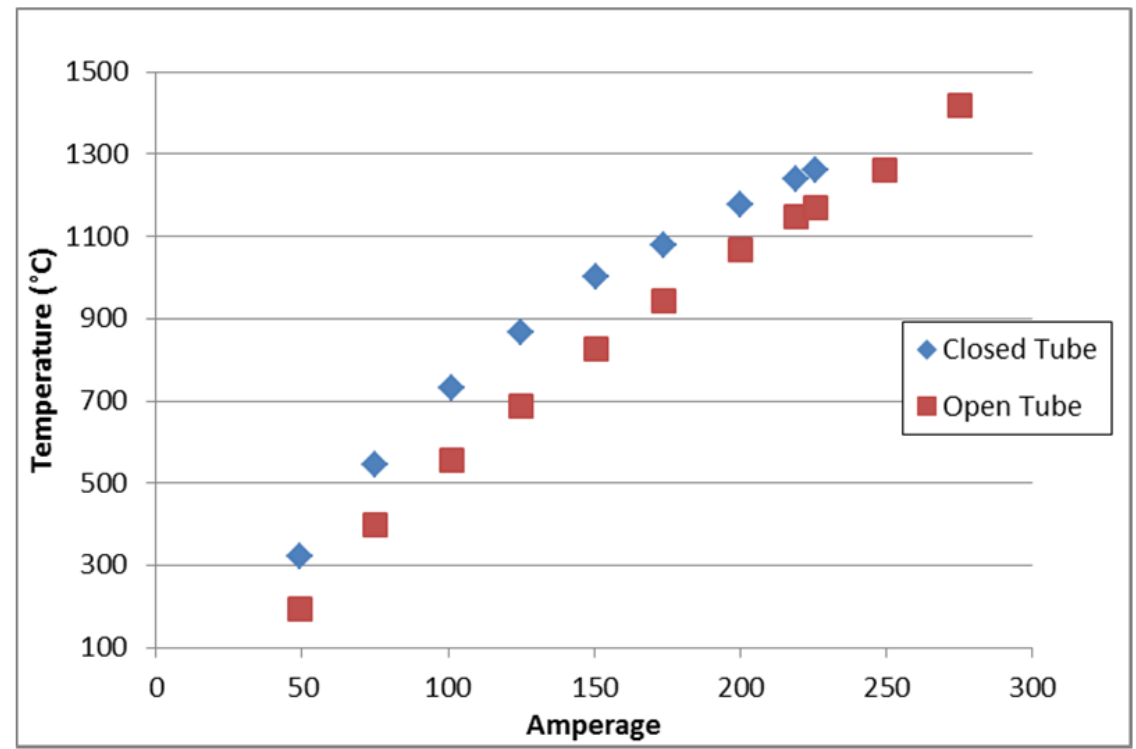

Figure 3-2. Amperage-Temperature Profiles for Open and Closed Tubes

In the second series of tests, the tubes were advanced through the induction field at a specified rate. Each tube was loaded into the sample holder and held in place with two set screws. The sample holder was secured in the sample advance mechanism with two other set screws. The sample is positioned with the bottom of the sample even with the top of the induction coil and the sample centered in the opening of the induction coil. Power to the induction coil was provided and the system operated for $30 \mathrm{~s}$ prior to advancing the sample through the induction coil.

The sample was then advanced regularly after a specified amount of time. Each advance entailed turning the sample advance mechanism five turns at $0.63 \mathrm{~mm} /$ turn (or $3.15 \mathrm{~mm} /$ advance). Because it was determined that 60 turns were sufficient to put all of the packing material into the center of the induction field, a total of 55-75 turns were used in each test for a total advance distance of 34.65-47.25 mm. Test conditions are listed in Table 3-4. During Test D, a continuous mist of deionized water was provided at 
the surface of the sample in the heated zone. This was accomplished through the use of a spray bottle with a mist setting.

Table 3-4. Conditions for Oxidation of Tube Segments in an Induction Field

\begin{tabular}{|c|c|c|c|c|c|c|c|}
\hline Test & Packing & $\begin{array}{l}\text { Packing } \\
\text { Pressure (psi) }\end{array}$ & $\begin{array}{c}\text { Packing } \\
\text { Depth (mm) }\end{array}$ & $\begin{array}{l}\text { Induction } \\
\text { Amperage }\end{array}$ & $\begin{array}{l}\text { Estimated } \\
\text { Temp }\left({ }^{\circ} \mathrm{C}\right)\end{array}$ & $\begin{array}{l}\text { Advance } \\
\text { Interval } \\
\text { (s) }\end{array}$ & \begin{tabular}{|c|c|}
$\begin{array}{c}\text { Advance } \\
\text { Distance } \\
(\mathbf{m m})\end{array}$ \\
\end{tabular} \\
\hline $\mathrm{A}^{*}$ & Fe metal & 8000 & 40.7 & 251.5 & 1350 & 15 & 47.25 \\
\hline $\mathrm{B}^{*}$ & Fe metal & 8000 & 44.5 & 251.5 & 1350 & 30 & 47.25 \\
\hline $\mathrm{C}^{*}$ & Fe metal & 8000 & 43.6 & 275.2 & 1425 & 15 & 47.25 \\
\hline $\mathrm{D}^{*}$ & Fe metal & 8000 & 38.0 & 251.5 & 1350 & 15 & 40.95 \\
\hline $\mathrm{E}^{*}$ & Fe metal & 8000 & 37.1 & 275.2 & 1425 & 30 & 40.95 \\
\hline $\mathrm{F}^{*}$ & Fe metal & 8000 & 38.0 & 251.5 & 1350 & 45 & 40.95 \\
\hline $\mathrm{G}^{*}$ & Ta metal & 8000 & 25.8 & 251.5 & 1350 & 60 & 40.95 \\
\hline $\mathrm{H}^{*}$ & Ta metal & 8000 & 24.9 & 275.2 & 1425 & 60 & 40.95 \\
\hline $\mathrm{I}^{*}$ & Ta metal & 8000 & 25.8 & 275.2 & 1425 & 90 & 40.95 \\
\hline $\mathrm{J}^{\#}$ & Empty & --- & --- & 251.5 & 1350 & 15 & 34.65 \\
\hline $\mathrm{K}^{\#}$ & Empty & --- & --- & 251.5 & 1350 & 30 & 34.65 \\
\hline \multicolumn{8}{|c|}{$\begin{array}{l}\text { * 304L stainless steel, } 12.6-12.7 \mathrm{~mm} \text { outside diameter, } 0.86-0.90 \mathrm{~mm} \text { wall thickness } \\
{ }^{\dagger} \text { Performed in steam environment by injecting a mist into the heated zone } \\
{ }^{*} \text { Alloy } 625,9.6 \mathrm{~mm} \text { outside diameter, } 0.95 \mathrm{~mm} \text { wall thickness }\end{array}$} \\
\hline
\end{tabular}

\subsection{Results and Discussion}

\subsection{Coupon Studies in a Muffle Furnace}

Testing with coupons (Table 3-1) showed a distinct oxidation behavior as a function of time and temperature. The test conditions and mass-increase data are provided in Table 4-1. The temperature effect can be seen best in the change of mass and thickness for Tests 1, 2, and 3. Apart from the Test 6 sample, the \% mass increase appears to plateau at 28-31\%. The thickness increase plateau was 135$145 \%$. A comparison of before and after samples for the coupons (Test 2) and tube segments (Test 9) is shown in Figure 4-1.

The samples were inspected and the coupons were subjected to flexing by hand. The samples from Tests $1,2,4$, and 5 retained some measure of flexibility, although a significant layer of the material delaminated from the sample. Pictures of the sample and some delaminated material are shown in Figure 4-2. The coupons from Tests 6 and 7 fractured without flexing. The fractured samples from these two tests are presented in Figure 4-3. A close examination of the sample from Test 7 (Figure 4-3, bottom) shows a thin piece of residual metal sample. The samples from Tests 8 and 9 fractured readily without flexing and exhibited sample cross-sections comparable to that of Test 6 (Figure 4-3, top). 
Table 4-1. Oxidation of 304L Stainless Steel Coupons and Tube Segments

\begin{tabular}{|c|c|c|c|c|c|c|c|c|}
\hline Test & $\begin{array}{c}\text { Sample } \\
\text { Type }\end{array}$ & $\begin{array}{c}\text { Temp } \\
\left({ }^{\circ} \mathrm{C}\right)\end{array}$ & $\begin{array}{l}\text { Time } \\
\text { (min) }\end{array}$ & $\begin{array}{c}\text { Initial } \\
\text { Mass (g) }\end{array}$ & $\begin{array}{c}\text { Final } \\
\text { Mass (g) }\end{array}$ & $\begin{array}{l}\text { \% Mass } \\
\text { Increase }\end{array}$ & $\begin{array}{c}\text { Final } \\
\text { Thickness } \\
\text { (mm) }\end{array}$ & $\begin{array}{c}\% \\
\text { Thickness } \\
\text { Increase }\end{array}$ \\
\hline 1 & Coupon* & 1350 & 15 & 4.7404 & 5.5267 & 16.6 & 2.06 & 77.6 \\
\hline 2 & Coupon* & 1350 & 30 & 4.5275 & 5.5922 & 23.5 & 2.15 & 85.3 \\
\hline 3 & Coupon* & 1350 & 60 & 4.5498 & 5.9677 & 31.2 & 2.81 & 142.2 \\
\hline 4 & Coupon* & 1375 & 15 & 4.5449 & 5.5131 & 21.3 & 2.24 & 93.1 \\
\hline 5 & Coupon* & 1375 & 30 & 4.6852 & 5.9651 & 27.3 & 2.71 & 133.6 \\
\hline 6 & Coupon* & 1375 & 60 & 4.4815 & 6.1728 & 37.7 & 3.23 & 178.4 \\
\hline 7 & Coupon* & 1400 & 15 & 4.5472 & 5.9102 & 30.0 & 2.13 & 83.6 \\
\hline 8 & Tube $^{\#}$ & 1375 & 60 & 9.060 & 11.6200 & 28.3 & 2.18 & 139.6 \\
\hline 9 & Tube $^{\#}$ & 1385 & 60 & 8.8677 & 11.5111 & 29.8 & 2.23 & 145.1 \\
\hline
\end{tabular}
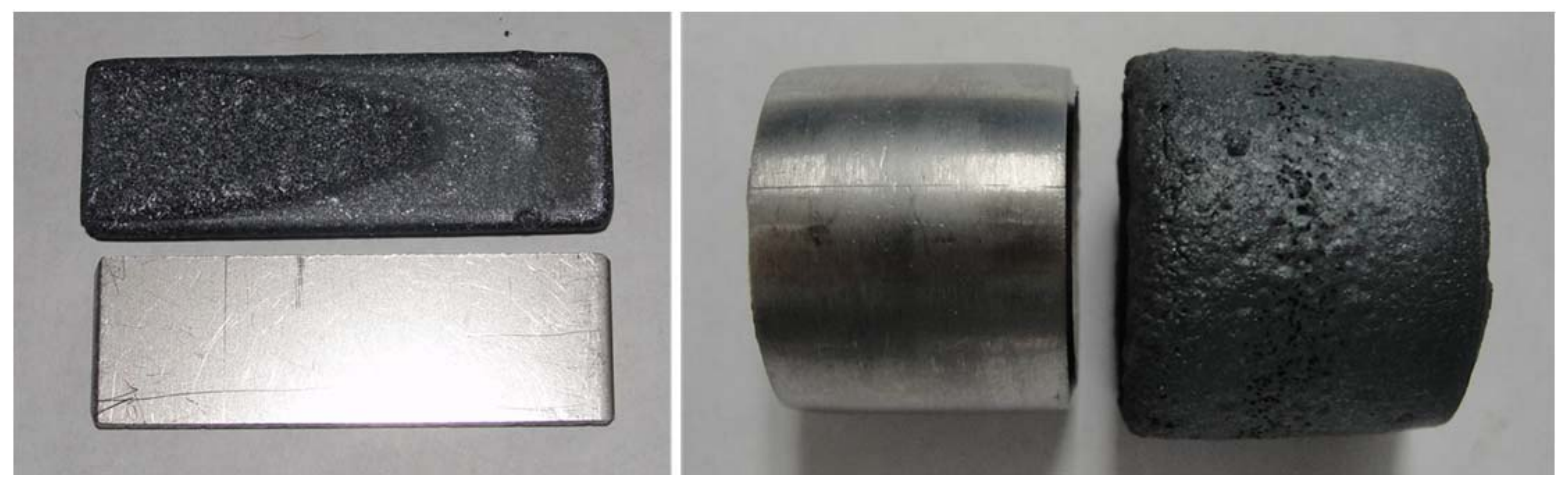

Figure 4-1. Comparison of Initial and Final Samples for Test 2 (left) and Test 9 (right)
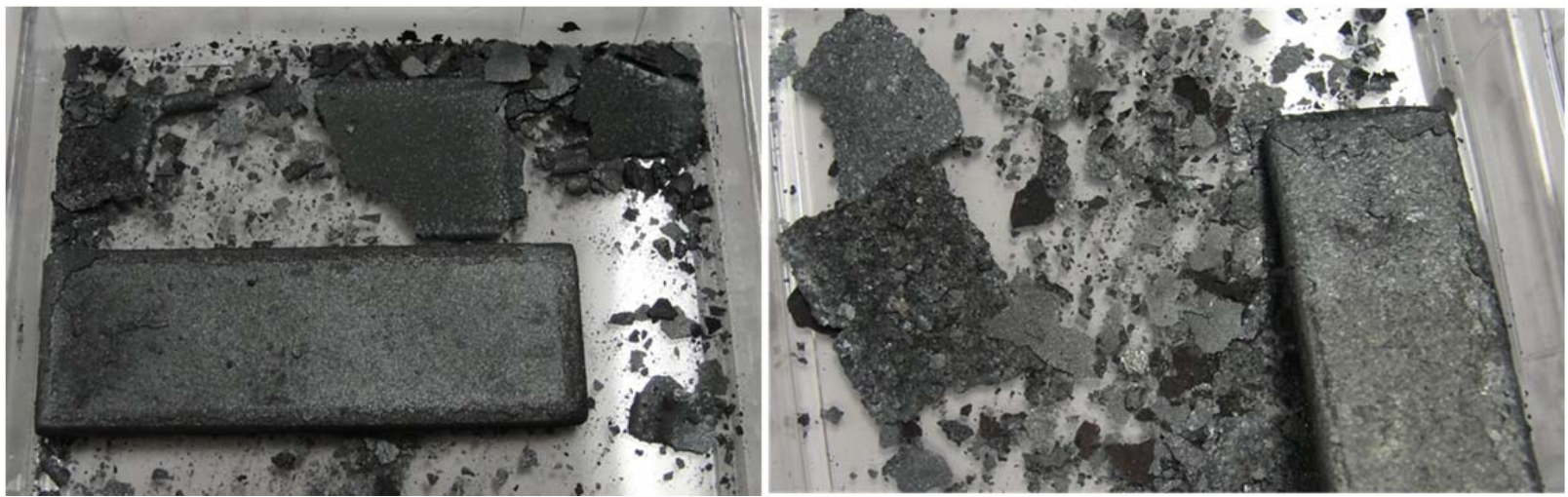

Figure 4-2. Comparison of Delaminated Samples for Test 1 (left) and Test 4 (right)

The oxidation studies confirmed that at $1375-1385{ }^{\circ} \mathrm{C}$, stainless steel coupons and tubing segments with material thicknesses about twice that of fuel cladding can be completely oxidized in 30-60 minutes. At $1400{ }^{\circ} \mathrm{C}$, oxidation occurs within 15 min but some melting of the steel also occurs. Oxidation in air at $1350{ }^{\circ} \mathrm{C}$ in a muffle furnace is prohibitively slow, which is consistent with the data in the literature. ${ }^{[9]}$ 
Once oxidized, the oxidized tube samples were sufficiently brittle to fracture with a small amount of compressive force. It is not known if the sample will fracture in tension due to an expanding powder within the oxidized tube.

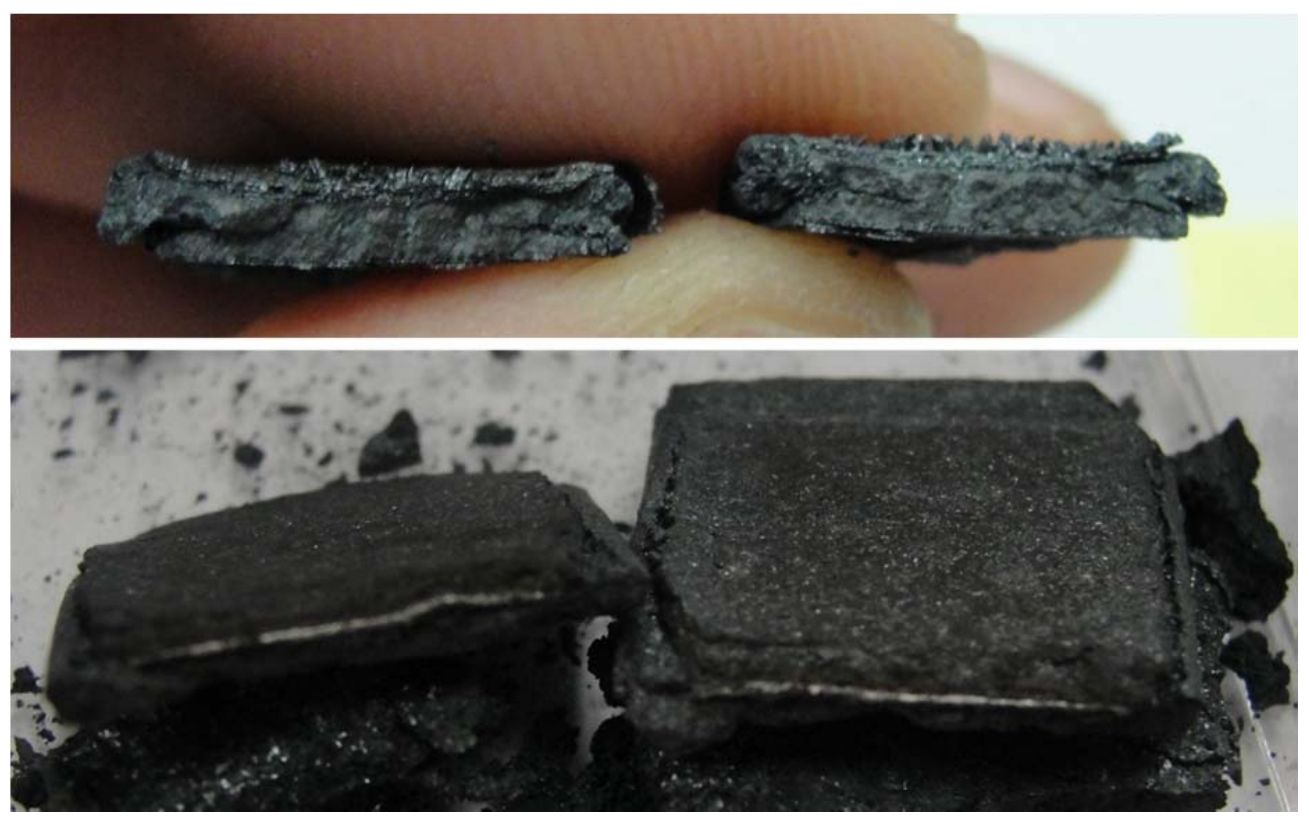

Figure 4-3. Fractured Samples for Test 6 (top) and Test 7 (bottom)

Samples from Tests 2, 5, 6, 7, 8, and 9 were analyzed by XRD. The data are provided in Table 4-2. XRD analyses of oxidized 304L identified chromite $\left(\mathrm{FeCr}_{2} \mathrm{O}_{4}\right)$, hematite $\left(\mathrm{Fe}_{2} \mathrm{O}_{3}\right)$, and wustite $(\mathrm{FeO})$ as major phases in oxidized material with no detectable residual metal. Awaruite $\left(\mathrm{FeNi}_{3}\right)$ was observed as a minor phase in the samples from Tests 5 and 9. Although the sample from Test 8 fractured readily, the XRD still shows a significant fraction of iron present as metal. The result from Test 8 (at $1375{ }^{\circ} \mathrm{C}$ ) is a contrast to the result from Test $9\left(1385^{\circ} \mathrm{C}\right)$, which shows no detectable unoxidized metal.

Table 4-2. XRD Data for Tests 2, 5, 7, 8, and 9

\begin{tabular}{|c|c|c|c|c|c|}
\hline Test & $\begin{array}{c}\text { Sample } \\
\text { Type }\end{array}$ & $\begin{array}{c}\text { Temperature } \\
\left({ }^{\circ} \mathbf{C}\right)\end{array}$ & $\begin{array}{c}\text { Time } \\
(\text { min) }\end{array}$ & $\begin{array}{c}\text { Major Crystalline } \\
\text { Phases }\end{array}$ & $\begin{array}{c}\text { Minor Crystalline } \\
\text { Phases }\end{array}$ \\
\hline 2 & Coupon & 1350 & 30 & $\mathrm{FeCr}_{2} \mathrm{O}_{4}, \mathrm{Fe}_{2} \mathrm{O}_{3}$ & \\
\hline 5 & Coupon & 1375 & 30 & $\mathrm{FeCr}_{2} \mathrm{O}_{4}, \mathrm{Fe}_{2} \mathrm{O}_{3}$ & $\mathrm{FeNi}_{3}$ \\
\hline 7 & Coupon & 1400 & 15 & $\mathrm{FeCr}_{2} \mathrm{O}_{4}, \mathrm{Fe}_{2} \mathrm{O}_{3}$ & \\
\hline 8 & Tube & 1375 & 60 & $\mathrm{FeCr}_{2} \mathrm{O}_{4}, \mathrm{Fe}, \mathrm{FeNi}$ & $\mathrm{Fe}_{2} \mathrm{O}_{3}, \mathrm{FeO}$ \\
\hline 9 & Tube & 1385 & 60 & $\mathrm{FeCr}_{2} \mathrm{O}_{4}, \mathrm{FeO}$ & $\mathrm{Fe}_{2} \mathrm{O}_{3}, \mathrm{FeNi}_{3}$ \\
\hline
\end{tabular}

Testing with 304L tubes packed with Fe, V, and Ta metal powders (Table 3-2) yielded different responses. Images of the tubes after oxidation in the muffle furnace at $1375{ }^{\circ} \mathrm{C}$ are provided for the tubes packed with Fe (Figure 4-4), V (Figure 4-5), and Ta (Figure 4-6). The side views of the Fe-packed tube exhibited increased embrittlement and cracking with increased times. In Figure 4-4, the packed Fe was sticking out of the end of the tube at the beginning of the experiment. As the test progressed, there appeared to be no growth of the packed material, either radially or axially, sticking from the tube. 
The side views for $\mathrm{V}$ and Ta clearly show the material packing depths as evidenced by the increased tube diameter. The end views for $\mathrm{V}$ and Ta indicate that $\mathrm{V}$ did not oxidize in the same manner as Ta. The edge of the $\mathrm{V}$ and Ta were not analyzed, but the appearance of the $\mathrm{V}$ is that of metal and $\mathrm{Ta}$ is that of oxide. Because of the results, Fe (because of availability) and Ta (because of oxidation behavior) were selected for the testing of packed tubes passing through an induction field.

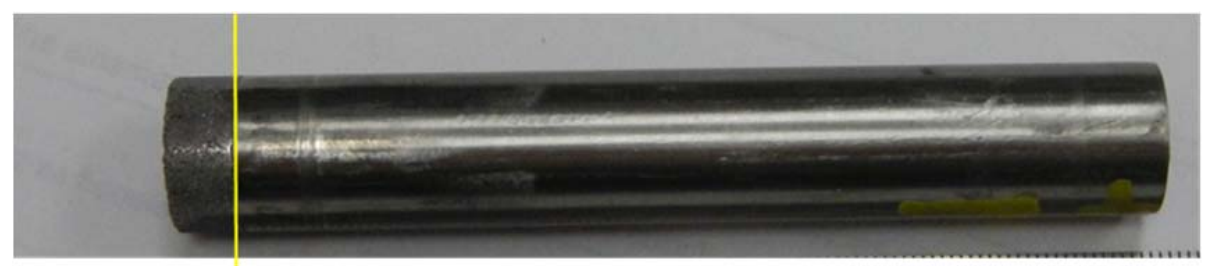

\section{Start}

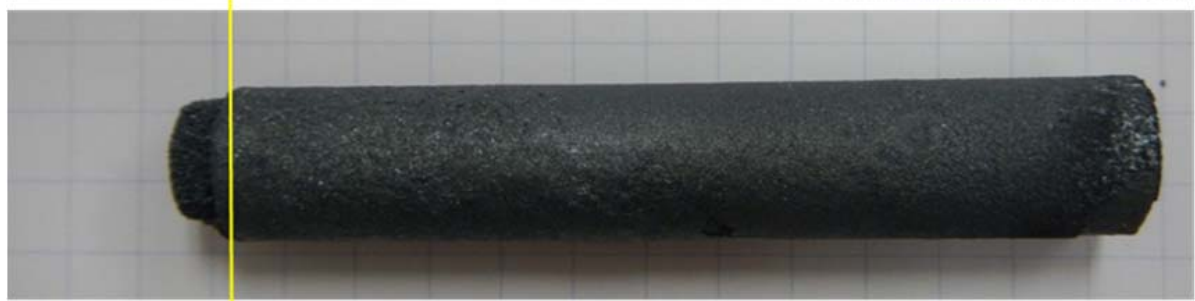

\section{$1 \mathrm{~h}$}

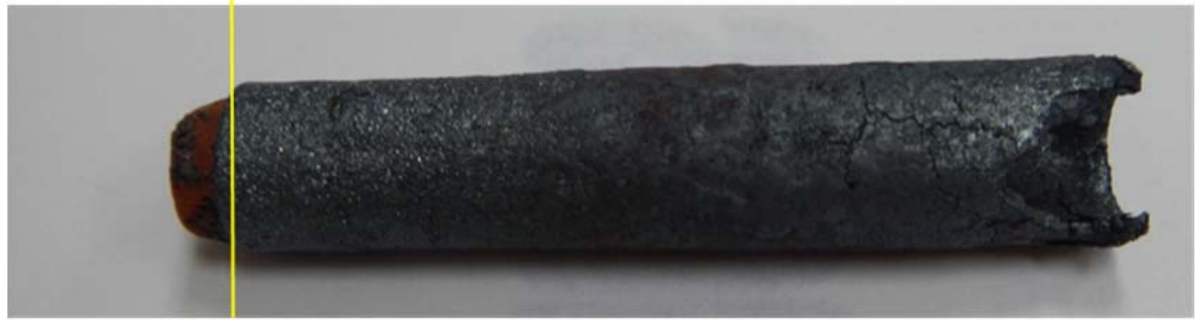

\section{$3 \mathrm{~h}$}
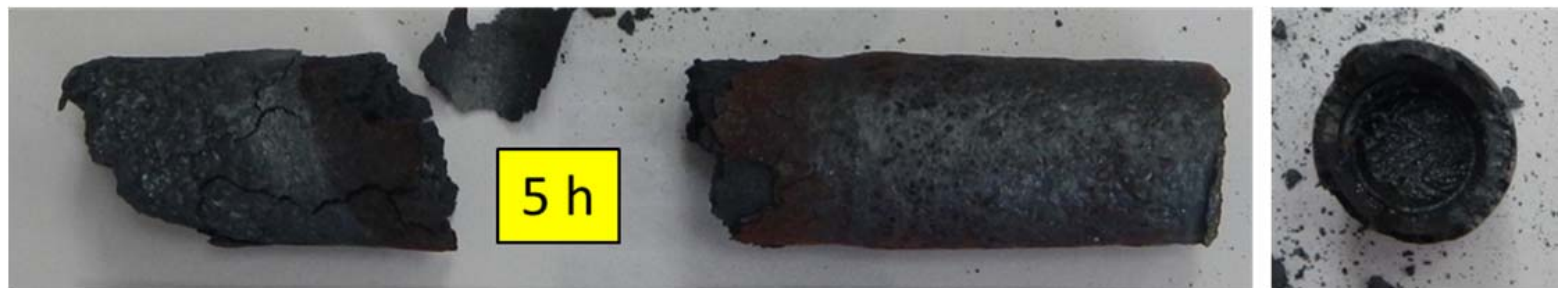

Figure 4-4. Tube Packed with Iron after Oxidation in Muffle Furnace at $1375{ }^{\circ} \mathrm{C}$
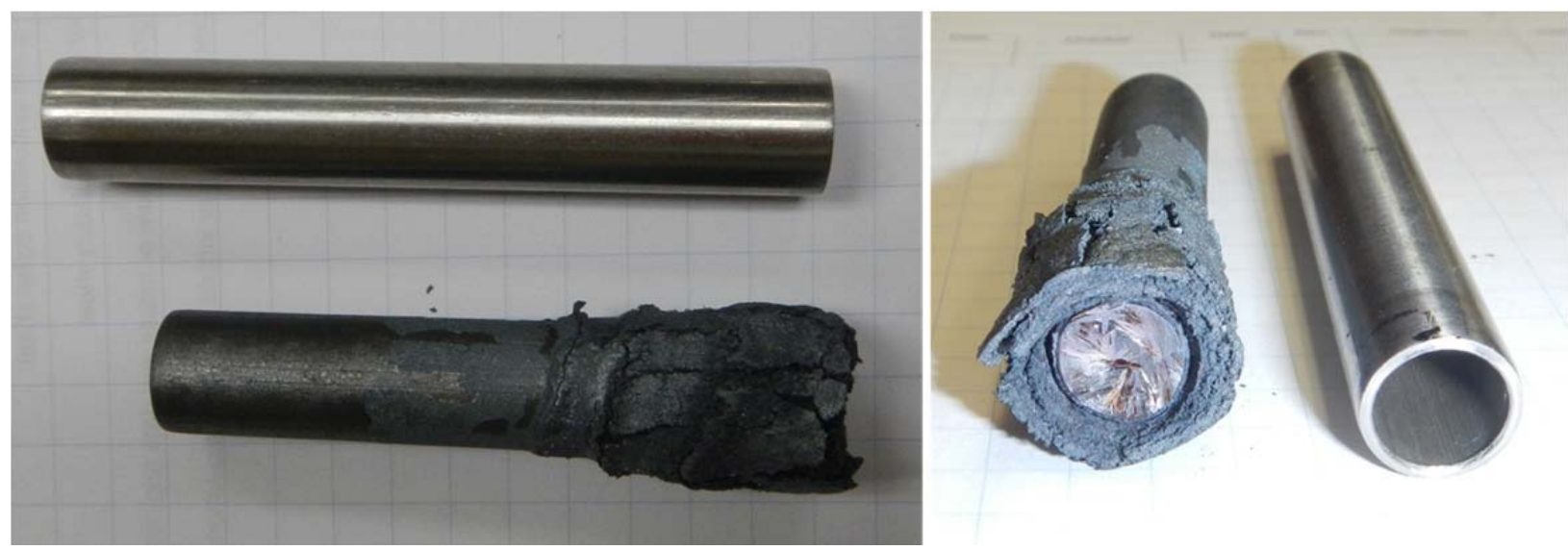

Figure 4-5. Tube Packed with Vanadium after Oxidation in Muffle Furnace at $1375{ }^{\circ} \mathrm{C}$ 

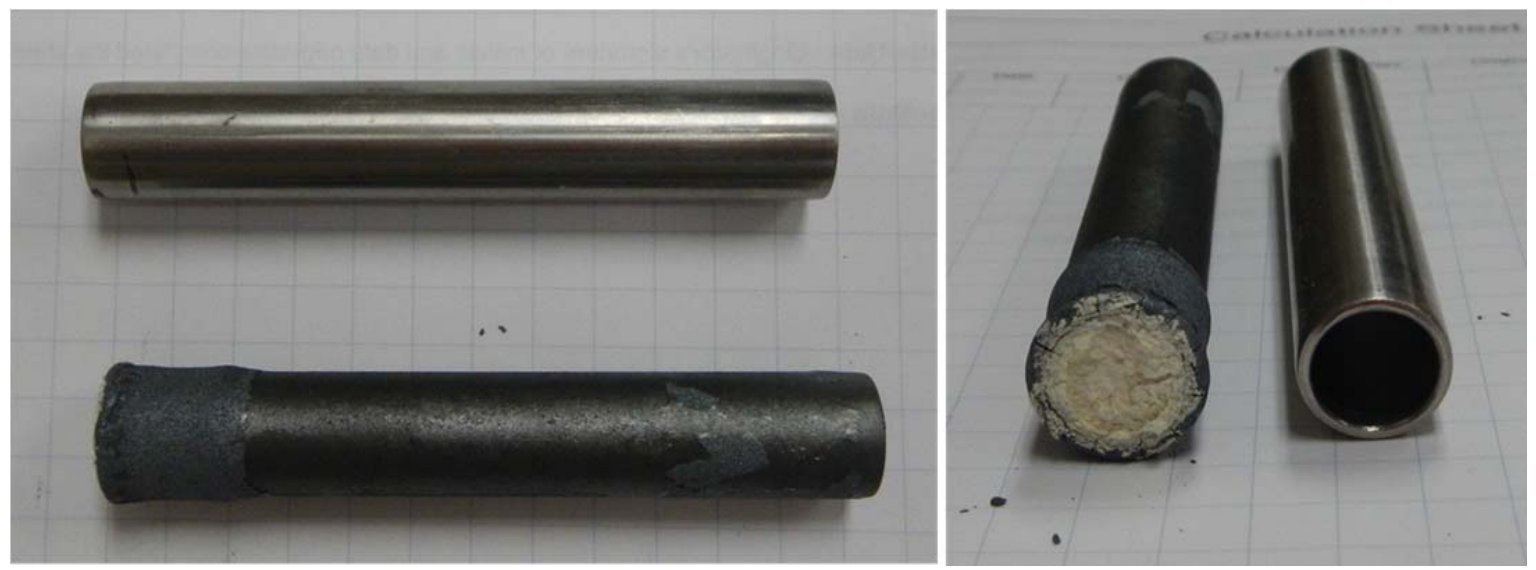

Figure 4-6. Tube Packed with Tantalum after Oxidation in Muffle Furnace at $1375{ }^{\circ} \mathrm{C}$

\section{2 $\underline{\text { Studies with Tubes in an Induction Field }}$}

A series of observations were made of each sample after heating in the induction field. Those observations are provided in Table 4-3. Stainless steel readily interacts with the induction field to produce rapid temperature increases in the tube. As discussed in Section 3.2, the actual temperature in the center of the tubes was not known. The temperatures can only be inferred from the data in Figure 3-2. The two test temperatures for the experiments listed in Table 4-3 were estimated at $1350{ }^{\circ} \mathrm{C}(251.5 \mathrm{amps})$ and $1425^{\circ} \mathrm{C}$ (275.2 amps). The melting point of 304L stainless steels is $1380{ }^{\circ} \mathrm{C}$. Pictures of Fe-packed tubes are in Figure 4-7 and Figure 4-8. Pictures of Ta-packed tubes are presented in Figure 4-9. Figure 4-10 and Figure 4-11 show the empty Alloy 625 tube after heating in the induction field.

Table 4-3. Observations for Oxidation of Tube Segments in an Induction Field

\begin{tabular}{|c|c|c|c|c|}
\hline Test & Packing & $\begin{array}{l}\text { Induction } \\
\text { Amperage }\end{array}$ & $\begin{array}{l}\text { Advance } \\
\text { Interval } \\
\text { (s) }\end{array}$ & Observations \\
\hline$A^{*}$ & Fe metal & 251.5 & 15 & Deep gouges are breaches in the tube wall \\
\hline $\mathrm{B}^{*}$ & Fe metal & 251.5 & 30 & Well-defined crack for length of metal powder \\
\hline$C^{*}$ & Fe metal & 275.2 & 15 & $\begin{array}{l}\text { Substantial damage. Difficult to distinguish between } \\
\text { melted tube and melted powder inside }\end{array}$ \\
\hline $\mathrm{D}^{*}$ & Fe metal & 251.5 & 15 & $\begin{array}{l}\text { Well-defined crack near the edge of the tube; not as long of } \\
\text { a crack as for Sample B }\end{array}$ \\
\hline$E^{*}$ & Fe metal & 275.2 & 30 & $\begin{array}{l}\text { Substantial damage. Difficult to distinguish between } \\
\text { melted tube and melted powder inside }\end{array}$ \\
\hline $\mathrm{F}^{*}$ & Fe metal & 251.5 & 45 & Small crack at the edge; no other holes \\
\hline $\mathrm{G}^{*}$ & Ta metal & 251.5 & 60 & Cracking occurring where powder expansion occurs \\
\hline $\mathrm{H}^{*}$ & Ta metal & 275.2 & 60 & Significant damage plus cracking where powder expands \\
\hline$I^{*}$ & Ta metal & 275.2 & 90 & Significant damage plus cracking where powder expands \\
\hline $\mathrm{J}^{\#}$ & Empty & 251.5 & 15 & $\begin{array}{l}\text { Significant wall damage; probing with a pointed object } \\
\text { reveals significant weakness in the wall }\end{array}$ \\
\hline $\mathrm{K}^{\#}$ & Empty & 251.5 & 30 & Less apparent damage than Sample J \\
\hline \multicolumn{5}{|c|}{$\begin{array}{l}\text { * 304L stainless steel, } 12.6-12.7 \mathrm{~mm} \text { outside diameter, } 0.86-0.90 \mathrm{~mm} \text { wall thickness } \\
\text { † Performed in steam environment by injecting a mist into the heated zone } \\
\text { \# Alloy } 625,9.6 \mathrm{~mm} \text { outside diameter, } 0.95 \mathrm{~mm} \text { wall thickness }\end{array}$} \\
\hline
\end{tabular}


Testing with tubes packed with either Fe- or Ta-packed tubes shows a large difference between the appearances after processing at 251.5 amps and 275.2 amps (Figure 4-7). At 275.2 amps, it appears that the tubes are melting. It is difficult to tell from visual observation the extent of breaching through the tube wall because the melted tube interacts to some degree with the Fe metal powder $\left(\mathrm{mp}=1535^{\circ} \mathrm{C}\right)$.

At 251.5 amps, the bump-filled surface observed at 275.2 amps is replaced with a smooth surface with distinct cracks. The appearance of the cracks at $251.5 \mathrm{amps}$ is depicted in Figure 4-8. The extent of cracking does not appear to be a function of dwell time, based on a comparison of the tubes from Tests A (15 s), B (30 s), and G (45 s). Tests A and B appear to have more visible damage than Test C. This may be attributable to variations in the tube material (e.g., wall thickness) or specific orientation within the induction field. The addition of a water mist (resulting in steam) in the heating area did not noticeably accelerate degradation of the tube, as was anticipated based on data in the literature. ${ }^{8}$ Although different quantities of steam and longer dwell times may increase the effect of steam, the objective was for the presence of steam to significantly reduce the operating temperature for the same dwell times at the expense of a more-complicated off gas stream. Those benefits do not appear to be realized in the short dwell times being employed in the induction field.

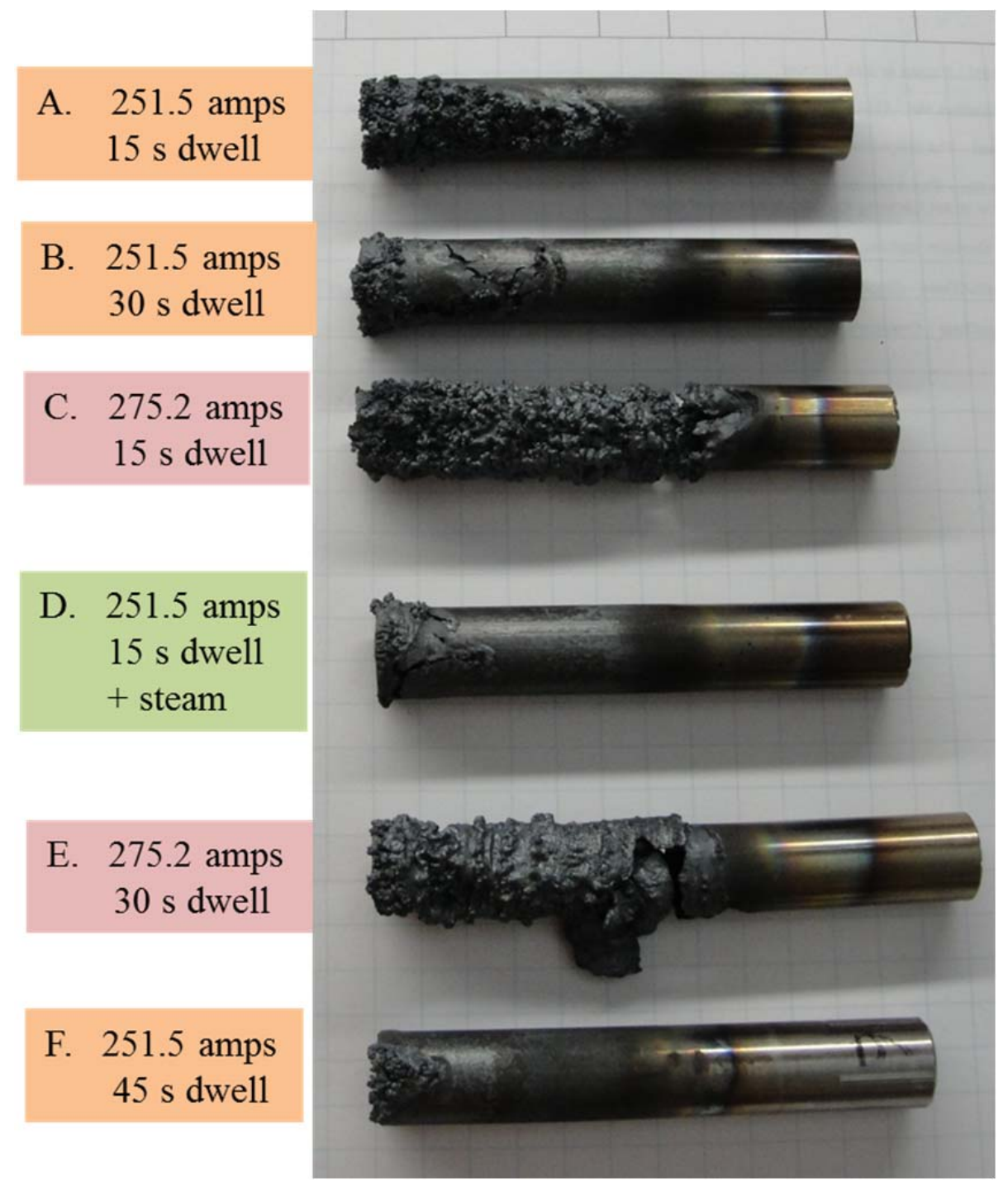

Figure 4-7. Tubes Packed with Iron after Oxidation in an Induction Field 


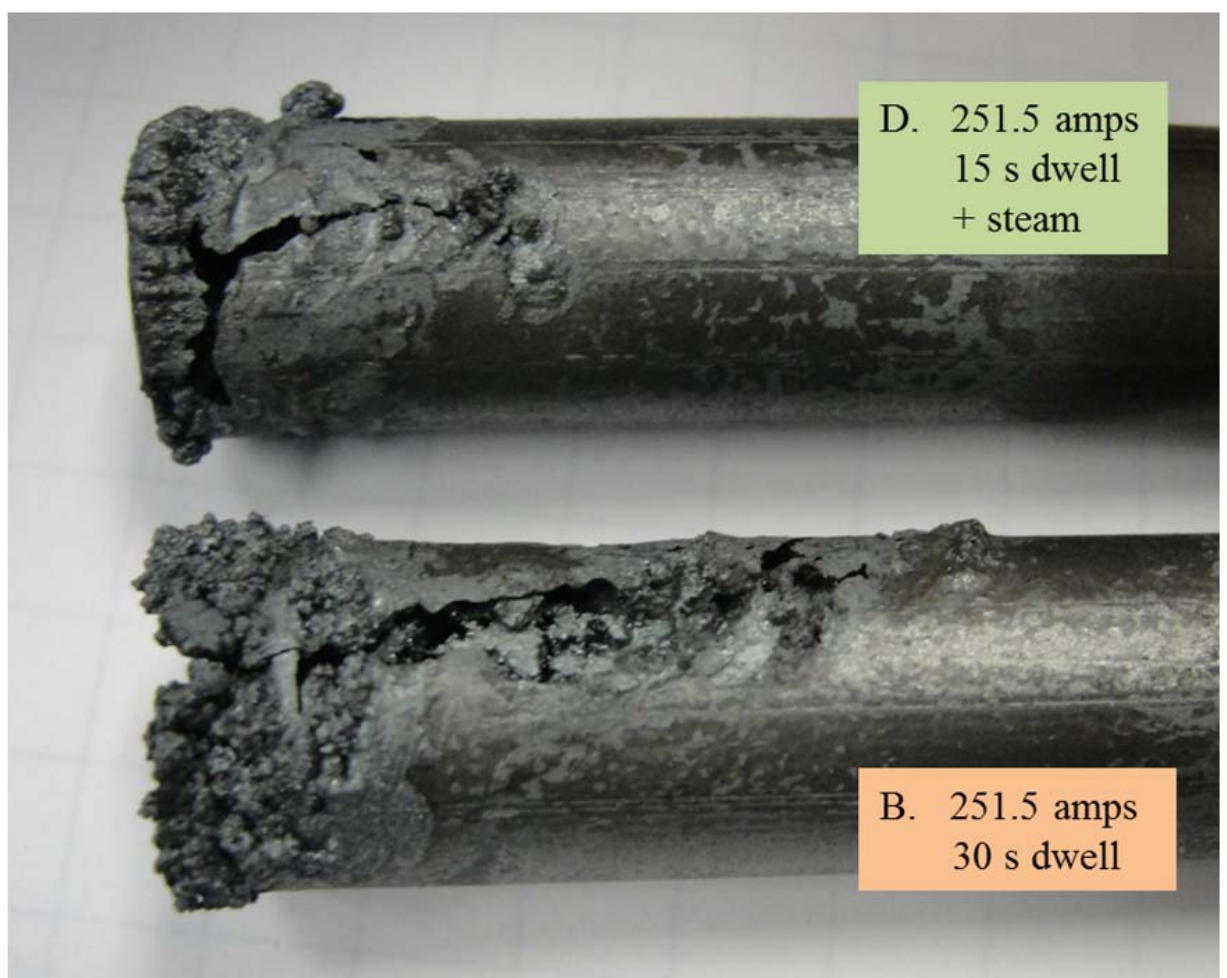

Figure 4-8. Comparison of Tubes $B$ and $D$ after Oxidation in an Induction Field

If the temperatures estimated in Table 3-4 are accurate, then significant damage is occurring at a temperature $\left(1350{ }^{\circ} \mathrm{C}\right)$ that was not sufficiently high to produce significant damage in the muffle furnace samples. The difference between the Fe-packed tube at $1375^{\circ} \mathrm{C}$ in the muffle furnace for $5 \mathrm{~h}$ (Figure 4-4) exhibits significantly less damage to the tubing than at $1350^{\circ} \mathrm{C}$ in the induction field for less than 10 min (Figure 4-8). It is not known whether this can be attributed directly or indirectly to the induction field. It may also be attributable to interaction between the Fe metal powder inside the tube with the induction field.

Testing with Ta metal powder also resulted in cracking of the tubes (Figure 4-9), but the cracking was not as extensive at 251.5 amps. The overall damage at the higher power setting of 275.2 amps was not as extensive either. It should be noted that the large holes visible in Samples $\mathrm{H}$ and I occur above the space occupied by Ta metal powder.

It can be seen in Figure 4-9 that the Ta metal has been oxidized to tantalum oxide $\left(\mathrm{TaO}_{2}\right)$, which expands due to its lower density compared to that of the metal powder. Some of the expansion is out the bottom of the tube. Consequently, the Ta expansion does not produce as much cracking of the tube. The same expansion out the bottom of the tube was not observed for the Fe-packed tubes in the induction field (Figure 4-7). 


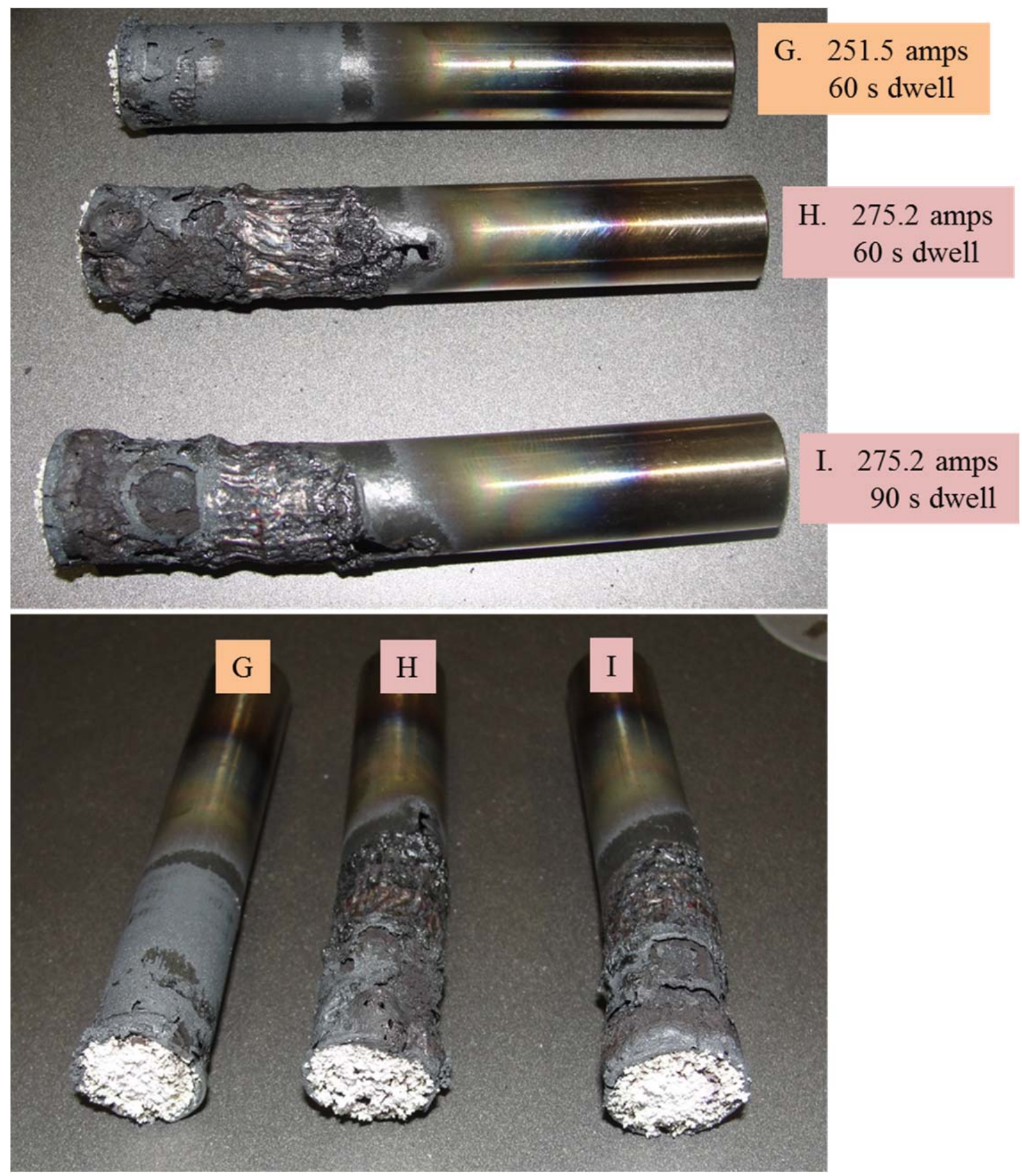

Figure 4-9. Tubes Packed with Tantalum after Oxidation in an Induction Field

Two tests were completed with empty segments of Alloy 625 tubing at the request of the customer to determine if the oxidation method behaved similarly for nickel-based alloys. Pictures from those two tests are shown in Figure 4-10 and Figure 4-11. Both tubes show significant damage at 251.5 amps. When the tube from Test $\mathrm{J}$ was probed with a pointed file (Figure 4-11), it was observed that the wall in the damaged area was weak and was readily breached. It is not known if there were holes prior to the probing. 


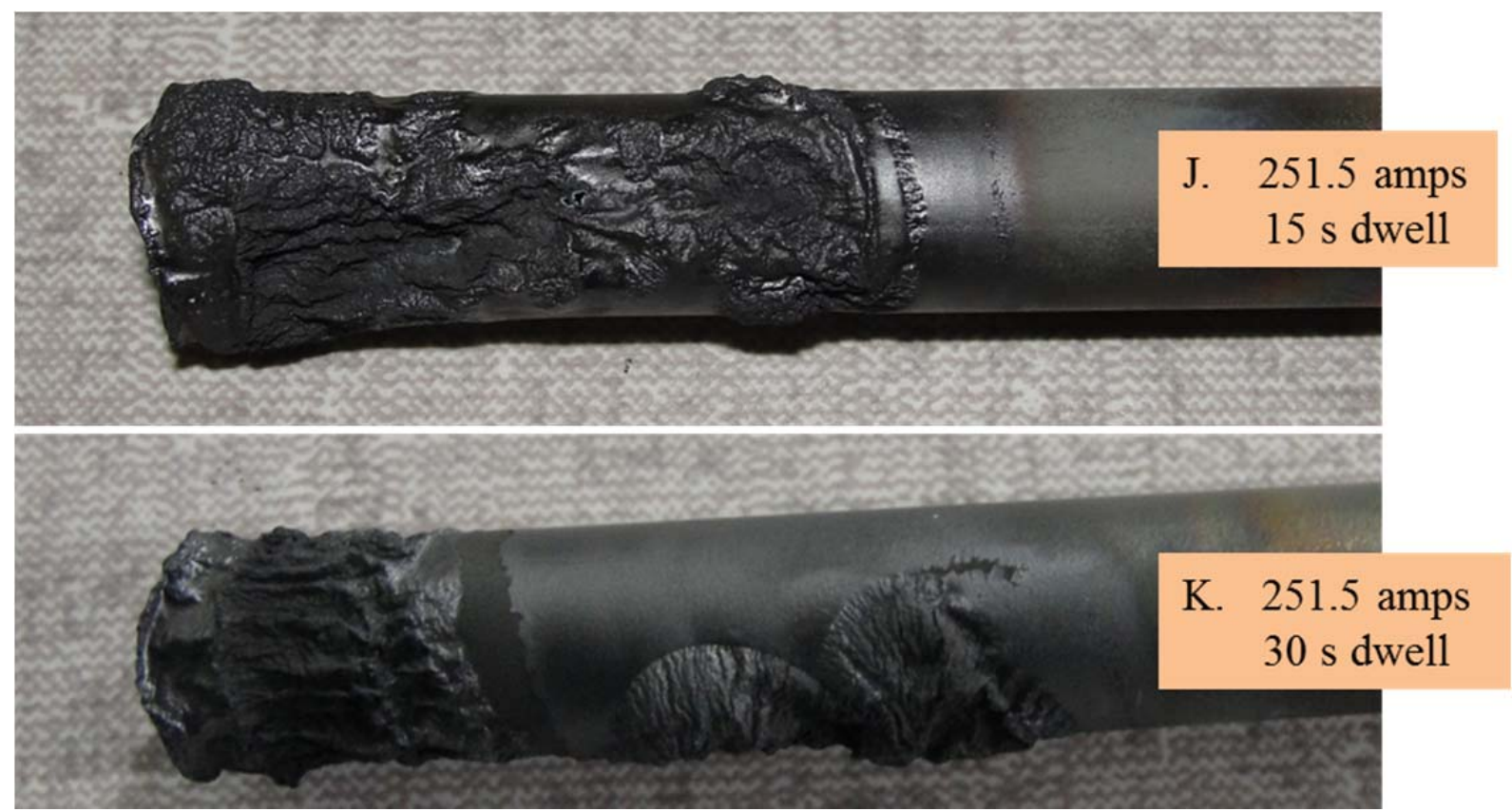

Figure 4-10. Empty Alloy 625 Tubes after Oxidation in an Induction Field
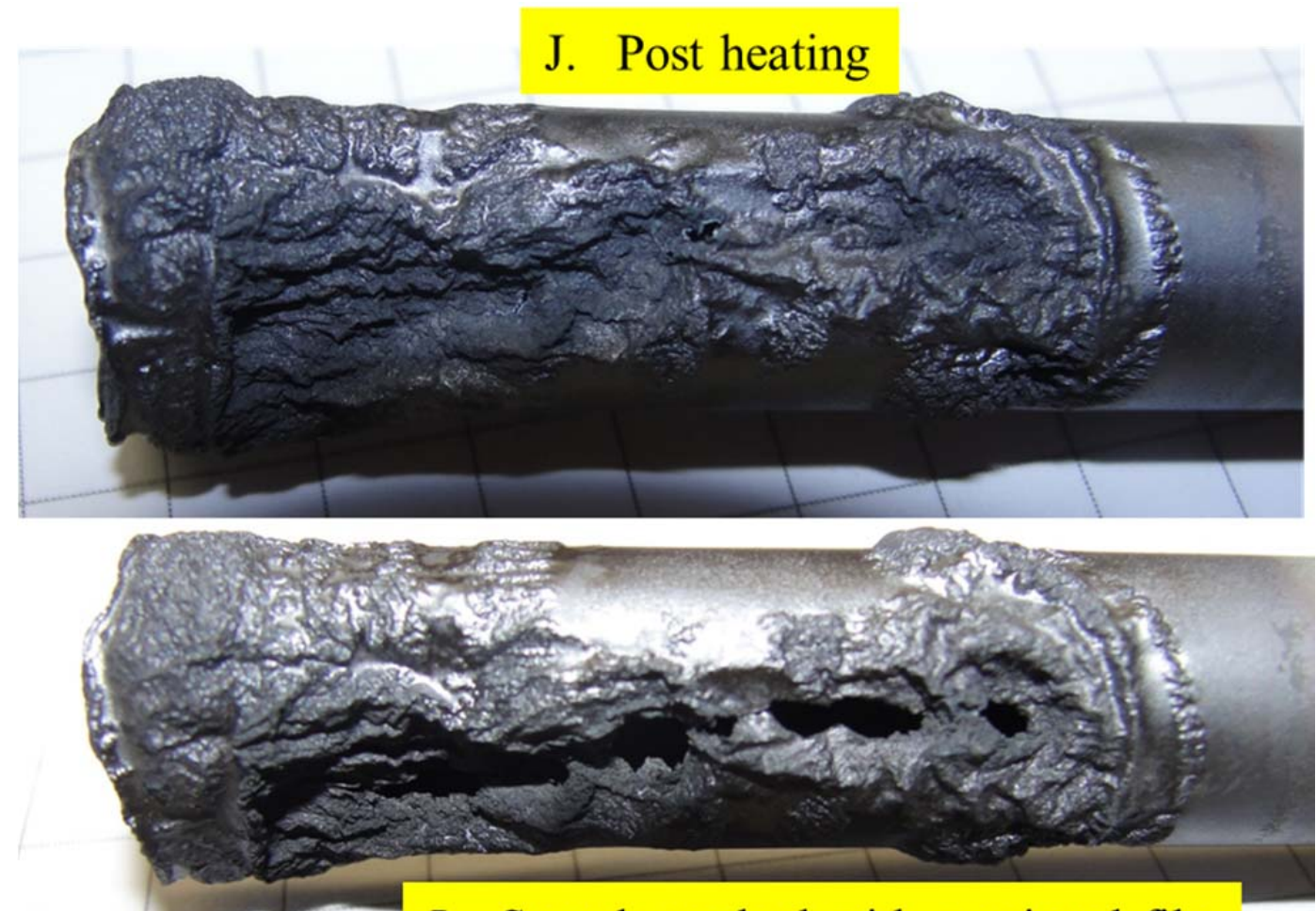

J. Sample probed with a pointed file

Figure 4-11. Empty Alloy 625 Tube after Oxidation in an Induction Field - Before Probing (top) and After Probing (bottom) 


\subsection{Conclusions}

The results of these scoping studies indicate that it may be possible to breach stainless steel clad fuels and access the fuel meat in a manner similar to the AIROX process. ${ }^{[8]}$ The approach taken involves oxidizing the tubing to make it brittle and crack, and then the $\mathrm{UO}_{2}$ fuel meat inside the tube oxidizes and expands to split the tubing open and expose the fuel meat.

Testing with 304L stainless steel coupons and tubes at elevated temperatures (1350-1425 $\left.{ }^{\circ} \mathrm{C}\right)$ has shown that $304 \mathrm{~L}$ tubing oxidizes to a brittle material comprised mostly of chromite $\left(\mathrm{FeCr}_{2} \mathrm{O}_{4}\right)$ and hematite $\left(\mathrm{Fe}_{2} \mathrm{O}_{3}\right)$. When 304L tubing is passed through an induction field to produce similar temperatures in the tube, the damage to the tube occurs faster and is more extensive than observed when heating the materials in a muffle furnace. Similar behavior was observed for tubing made from nickel-based Alloy 625.

Experiments using tubes packed with $\mathrm{Fe}, \mathrm{V}$, and Ta metal powders showed that if the material inside the tube expands while the tube is made brittle through oxidation, cracking and perforation of the tube will occur along the length of the tube. The extent of cracking was dependent upon metal powder used for testing. It is not known if any of the materials tested accurately represent the effect of $\mathrm{UO}_{2}$ inside stainless steel tubes expanding as it is oxidized to $\mathrm{U}_{3} \mathrm{O}_{8}$ (30\% expansion).

For Fe-packed tubes, significant cracking occurred at $\sim 1350{ }^{\circ} \mathrm{C}$ and melting of the tube was evident at $\sim 1425^{\circ} \mathrm{C}$. The extent of tube cracking or damage did not appear to be a function of dwell time from 1545 seconds. For Ta-packed tubes, minor cracking occurred at $\sim 1350{ }^{\circ} \mathrm{C}$ with more extensive cracking and tube degradation at $\sim 1425^{\circ} \mathrm{C}$; however, the tube appearance after testing is very different from that of the Fe-packed tubes at the same temperature. The presence of a water mist (which turns to steam) in the heating zone did not visibly change the magnitude of tube degradation.

\subsection{Future Work}

At the current stage of development, it is envisioned that the next stage of trials would involve work with an unirradiated fuel rod, preferably fabricated with natural or depleted uranium. The trials could be conducted in the SRNL Fab Lab. An unirradiated fuel rod would be fed slowly in air into an induction field to allow oxidation of the cladding. Testing would have to be conducted at varying power settings and feed rates.

Consideration should also be given to the length of the induction field. What would be the impact of a longer field? While it might accelerate the process, might it also have negative impacts? For example, if a rod were oxidized all at once, it could fracture first in the middle and fall into the bottom of a holding container. However, the broken pieces might also get lodged in the coil or damage the coil through contact of the cold coil with hot materials.

The first proposed approach is to gradually feed the tube into a heating zone so that oxidation of the metal is gradually up the tube and fracture of the tube occurs first at the bottom and then progresses up the tube. This approach may be necessary to produce behavior in the tube similar to that of chop-leach (i.e., fracturing in small segments to expose the fuel meat). Based on preliminary studies described, it is expected that the rod will retain its mechanical integrity and not form a series of small segments. 


\subsection{References}

1. W. D. Bond, J. C. Mailen, and G. E. Michaels, "Evaluation of Methods for Decladding LWR Fuel for a Pyroprocessing-Based Reprocessing Plant”, ORNL/TM-12104, January 1994.

2. G. F. Kessinger and M. C. Thompson, “Chop-Leach Dissolution of Commercial Reactor Fuel”, AIP Conference Proceedings, 2003, 673(1), 288.

3. P. D. Gupta, “Laser Applications in Indian Nuclear Power Programme”, Energy Procedia 00(2010), Elsevier Publishing, www.sciencedirect.com.

4. D. E. Eyler, "H Canyon Cold Crucible Induction Melter (CCIM) and Fuel Shear/Leach Estimates", SRNL-L0000-2012-00505-DEP, March 30, 2012.

5. R. E. Blanco, L. M. Ferris, and D. E. Ferguson, “Aqueous Processing of Thorium Fuels”, ORNL-3219, February 1962.

6. B. C. Finney and B. A. Hannaford, "Sulfex Process: Engineering-Scale Semicontinuous Decladding of Unirradiated Stainless Steel-Clad $\mathrm{UO}_{2}$ and $\mathrm{UO}_{2}-\mathrm{ThO}_{2}$ ", ORNL 3072, March 1961.

7. R. E. Blanco, L. M. Ferris, and C. D. Watson, "Preparation of Stainless Steel, Zirconium, and Graphite Clad and Base Reactor Fuels for Solvent Extraction”, ORNL-TM-131, January 1962.

8. L. F. Grantham, R. G. Clark, R. C. Hoyt, and J. R. Miller, “AIROX Dry Pyrochemical Processing of Oxide Fuels”, Actinide Separation, ACS Symposium Series 117, 1980, 219-232.

9. J. T. Bittel, L. H. Sjodahl, and J. F. White, “Oxidation of 304L Stainless Steel by Steam and by Air”, Corrosion - NACE, 1969, 25(1), 7-14.

10. R. Guillamet, J. Lopitaux, B. Hannoyer, and M. Lenglet, “Oxidation of Stainless Steels (AISI 304 and 316) at High Temperature”, J. de Physique IV, Colloque C9, 1993, 3, 349-356.

11. T. Ishida, U. Harayama, and S. Yaguchi, "Oxidation of 304 Stainless Steel in High-Temperature Steam”, J. Nucl. Mat., 1986, 140, 74-84.

12. "Revised Thermocouple Reference Tables, Type S", www.omega.com/temperature/Z/pdf/z208209.pdf, September 22, 2014. 


\section{Distribution:}

T. M. Adams, 773-41A

W. F. Bates, 703-H

T. B. Brown, 773-A

T. B. Calloway, 999-2W

S. D. Fink, 773-A

C. C. Herman, 773-A

D. T. Herman, 735-11A

D. T. Hobbs, 773-A

E. N. Hoffman, 999-W

S. L. Marra, 773-A

M. C. Thompson, 773-A
J. C. Marra, 999-2W

G. M. Maxted, 703-H

D. H. McGuire, 999-W

F. M. Pennebaker, 773-42A

R. A. Pierce, 773-A

T. C. Shehee, 773-A

R. M. Sprague, 773-A

J. R. Jackson, 703-46A

Records Administration (EDWS) 